Article

\title{
New Anti SARS-Cov-2 Targets for Quinoline Derivatives Chloroquine and Hydroxychloroquine ${ }^{\dagger}$
}

\author{
Davide Gentile ${ }^{1}$, Virginia Fuochi ${ }^{2}\left[\right.$, Antonio Rescifina ${ }^{1, *(\mathbb{D}}$ and Pio Maria Furneri ${ }^{2, *}$ (i) \\ 1 Dipartimento di Scienze del Farmaco, University of Catania, 95125 Catania, Italy; davide.gentile@unict.it \\ 2 Dipartimento di Scienze Biomediche e Biotecnologiche, University of Catania, 95125 Catania, Italy; \\ vfuochi@unict.it \\ * Correspondence: arescifina@unict.it (A.R.); furneri@unict.it (P.M.F.) \\ + In memory of Professor Carmela Spatafora, a friend, colleague and distinguished scientist, on the fourth \\ anniversary of her premature death.
}

Received: 8 July 2020; Accepted: 12 August 2020; Published: 14 August 2020

\begin{abstract}
The rapid spread of severe acute respiratory syndrome coronavirus 2 (SARS-CoV-2) has created a severe global health crisis. In this paper, we used docking and simulation methods to identify potential targets and the mechanism of action of chloroquine (CQ) and hydroxychloroquine (HCQ) against SARS-CoV-2. Our results showed that both CQ and HCQ influenced the functionality of the envelope (E) protein, necessary in the maturation processes of the virus, due to interactions that modify the flexibility of the protein structure. Furthermore, CQ and HCQ also influenced the proofreading and capping of viral RNA in SARS-CoV-2, performed by nsp10/nsp14 and nsp10/nsp16. In particular, HCQ demonstrated a better energy binding with the examined targets compared to CQ, probably due to the hydrogen bonding of the hydroxyl group of HCQ with polar amino acid residues.
\end{abstract}

Keywords: SARS-CoV-2; chloroquine; hydroxychloroquine

\section{Introduction}

In recent years, two $\beta$-coronaviruses ( $\mathrm{CoVs}$ ) have caused outbreaks of pneumonia, the severe acute respiratory syndrome (SARS), and the Middle Eastern respiratory syndrome (MERS) [1]. COVID-19 is a disease caused by a new coronavirus known as severe acute respiratory syndrome coronavirus 2 (SARS-CoV-2), which leads to respiratory failures such as the previous SARS-CoV and MERS-CoV [2,3]. On 11 March, 2020, the World Health Organization characterized COVID-19 as a pandemic [4]. The outbreak started in mid-December 2019 in Wuhan, China [2,5]. Today, it is not possible to define with certainty the route taken by the virus to reach humans; but numerous assumptions agree with the animal origin [6-8]. Most likely, SARS-CoV-2 might have cryptically circulated within humans for years before being discovered [9].

Subsequently, due to the high contagiousness, this coronavirus spread worldwide very quickly [10]. CoVs belong to the subfamily Orthocoronavirinae of the Coronaviridae family, whose genome is a single-stranded, positive-sense RNA.

The reproductive cycle of coronaviruses is particularly elaborate and complex [11], and can be divided into two different translational and transcriptional moments, which are strongly linked to the action capacity of many antiviral drugs. Although numerous papers have been published on the activity and molecular mechanisms of different antiviral molecules, no molecules having a marked and specific activity have yet been found. Among the most discussed drugs of the last five months, CQ and its HCQ derivative have been the subject of numerous in vitro and clinical studies [12-16].

CQ was synthesized for the first time by H. Andersag in Bayer laboratories in Elberfeld in 1934 [17]. Initially studied also in vivo for its antimalarial activity, was abandoned in favor of quinacrine 
hydrochloride, a less toxic molecule $[17,18]$. Rediscovered in America during the Second World War, it was marketed in 1947 [17,19-23]. Its structural formula derives from a molecule of natural origin, quinine, from which it differs for the substituents at position 6 and the position linked to chain $4[17,18]$. Although CQ was used for many years as both antimalarial prophylaxis and therapy, its use has been significantly reduced due to the onset of resistance, especially in Plasmodium falciparum [24]. Its antimetabolic activity has been reported since the first studies with particular reference to the inhibition of numerous enzymatic pathways in plasmodia [24], and inhibition of DNA polymerase and RNA polymerase in bacteria [25-27], as well as in Tetrahymena pyriformis, a ciliated protozoa [28]. Although CQ targets plasmodia, unfortunately, the same inhibitory effects have been demonstrated in a model developed in vivo on rats [29]. However, the antiprotozoal mechanism was subsequently associated with its lysosomotropic characteristics and its interaction with hemozoin [30]. The antiviral activity, described in the early 1960s, was initially deduced from a clinical study on the therapy of viral hepatitis [31], and then described in Mouse Hepatitis Virus (MHV, murine Beta Coronavirus) experimentally [32]. In this case, the six-hour treatment with CQ of mouse peritoneal macrophages infected with MHV reduced the viral load compared to those of the untreated cells. However, after $72 \mathrm{~h}$ from the treatment, an increase in the viral load was noted.

Consequently, the author concluded that this phenomenon was due in some way to a higher permeability of lysosomes. The antiviral activity was later demonstrated in DNA phages [33]. CQ was also reported to inhibit other viruses such as Encephalomyocarditis virus (Cardiovirus), Sindbis virus, Influenza A2, Newcastle disease virus, Herpes simplex, and Vaccinia [34]. A study on the antiviral activity against myxoviruses allowed the authors to argue that probably the mechanism of action was to inhibit stripping through the so-called stabilization of lysosomal membranes [35]. In 1974, the first in vivo study on CQ activity was conducted in a model of infection with Moloney Murine Sarcoma virus (a murine retrovirus), which has shown that CQ inhibited the development of the tumor when preventively inoculated at a concentration of $50 \mathrm{mg} / \mathrm{kg}$ in the newborn mouse [36]. Numerous other reports were published regarding other animal and human viruses that attributed its antiviral activity to lysosomotropy [37-40]. However, this feature and its real antiviral activity has not been more confirmed in MHV [41]. Furthermore, some viruses, such as poliovirus, seem to be insensitive up to the concentration of $150 \mu \mathrm{M}[42,43]$.

Particular interest has aroused the ability of CQ to inhibit both HIV replication and glycosylation of viral particles and, at the same time, to act in synergy with the viral protease [44]. Furthermore, impairment of ACE2 terminal glycosylation has been reported. In fact, at $25 \mu \mathrm{M} C Q$, although ACE2 is expressed in similar quantities at the cell surface, the variations in its glycosylation status might render the ACE2/SARS-CoV interaction less efficient and inhibit virus entry when the cells are treated with the drug [45]. The same authors have also shown inhibition of endosome-mediated viral entry.

Another quinoline derivative has been considered capable of inhibiting viral replication: In fact, the hydroxychloroquine, a well-known antimalarial drug recognized as a life-saving drug from the WHO (https://www.who.int/medicines/publications/essentialmedicines/en/), has also been used in the treatment of arthritic complications during some viral infections $[46,47]$. HCQ has also been shown to inhibit the replication of HIV by a mechanism similar to that of chloroquine [48,49]. A hypothetical anti-HPV activity of HCQ has also been proposed [50].

HCQ has recently been the subject of renewed interest both as a therapy for the disease caused by SARS-CoV-2 [51-53], and prophylaxis [54]. Interestingly, HCQ can intervene as a competitor for absorption by binding to the cellular receptor [55], or onto iron homeostasis [56].

Looking for possible antiviral molecules, many new targets have been found in numerous nonstructural proteins [57-61], but insufficient attention has been paid to the role of the nsp10/nsp14 complex [62], and the envelope (E) protein [63].

This study aimed to investigate the molecular interaction of CQ or HCQ with three nonstructural proteins of SARS-CoV-2 that could represent a new and more useful target of the two drugs. In fact, it has been recently suggested that nsp10 and nsp16 could be an innovative target for antiviral drug 
discovery [64]. These features could be an innovative and exciting explanation by which the mechanism of quinoline derivatives might be directed more to the late replicative process rather than to uncoating.

\section{Results and Discussion}

\subsection{E Protein}

E protein is a short peptide of 75 amino acids in SARS-CoV-2 [63]. It is organized in three different domains: $N$-terminal, transmembrane (with most hydrophobic amino acids), and $C$-terminal $[63,65]$. E protein is one of the major structural proteins of the coronavirus [66], and is essential for infection as well as for bending membranes, and playing a role in virus maturation processes [67]; in fact, in $\mathrm{CoV}$ assembly, the formation of the envelope requires the only expression of $\mathrm{M}$ and $\mathrm{E}$ and not $\mathrm{N}$. Moreover, the ability of $\mathrm{E}$ and $\mathrm{M}$ to drive the formation of a virus-like particle clearly shows that $\mathrm{E}$ is essential for assembly [68]. Moreover, E protein interacts with the host proteins [69], as well as influences host cell membrane permeability $[63,70]$, and it has been associated with different membrane topologies $[63,68,71,72]$. In fact, it has been described, with a low frequency, a version with an $\mathrm{N}$-glycosylation [71] of asparagine in position 66 [72]. Its functions as an ion-channeling viroporin [73], shared with two other proteins $[68,74,75]$, have been associated with inflammation observed in acute respiratory distress [76] as well as to endoplasmic reticulum stress. At the same time, its role in cellular apoptosis remains questionable [63]. In addition, the $\mathrm{Ca}^{2+}$ passage to E protein channel has been associated with the activation of NLSP3 inflammasomes [76,77]. Although not crucial for virus multiplication, the absence of E protein showed an accumulation of probably aberrant virions [78]. Its interaction with PALS1, a particular class of tight junction-associated protein, has been associated with damage to lung epithelium [79]. E protein may represent a novel strategy used by SARS-CoV to increase its virulence [80], and, although it is not involved in the innate immune response to SARS-CoV, it might have an important role in developing a vaccine strategy as well as might be an important target for a chemotherapeutic approach $[66,80,81]$.

The great difficulty of crystallization for a hydrophobic protein did not allow the study and design of selective inhibitors for E protein. Given the low reliability of the homology model obtained and of the models present on the web, in addition to the lack of data in the literature on the design of inhibitors, we decided to investigate the entire pentameric structure using the NMR structure of $\mathrm{E}$ protein from SARS-CoV-1 [82]. A comparative sequence analysis via Multalin reveals that SARS-CoV-1 and SARS-CoV-2 E protein sequences share $94.7 \%$ identity amongst themselves. The results of the molecular docking (Figures 1 and 2, Figures S1 and S2) showed that HCQ has better binding energy $(-8.6 \mathrm{kcal} / \mathrm{mol})$ than CQ $(-8.3 \mathrm{kcal} / \mathrm{mol})$. The docking pose highlights that the interactions between HCQ and the E Protein are due to the hydrogen bond with the Phe23 residue, while the drug quinolinic region is stabilized by the hydrophobic bonds with the five-phenyl residues Phe26 in the central part of the ion channel (Figure 2 and Figure S2). Other hydrophobic interactions concern the aliphatic area of the drug with the residues Leu19, Ala22, Val25, and Val29. To obtain detailed information on the structural characteristics of the protein-drug complex, molecular dynamics (MD) simulations were performed using the YASARA software; the analysis of the MD trajectories showed excellent stability of the complex as highlighted in the graphs of Figure S2. It is interesting to note that, at medium HCQ laying, it establishes a new hydrogen bond between the amino nitrogen and the Phe26 residue, with an average distance of $1.82 \AA$, while the hydroxyl group establishes a hydrogen bond with Leu65, with an average distance of $1.74 \AA$. Both hydrogen bonds are stable throughout the MD simulations. The re-docking $(-10.6 \mathrm{kcal} / \mathrm{mol})$ performed on the average laying confirmed the excellent stability of the complex favored both by the hydrogen bonds and by the hydrophobic interactions inside the central cavity with the Phe26 residue of the pentamer. 
A

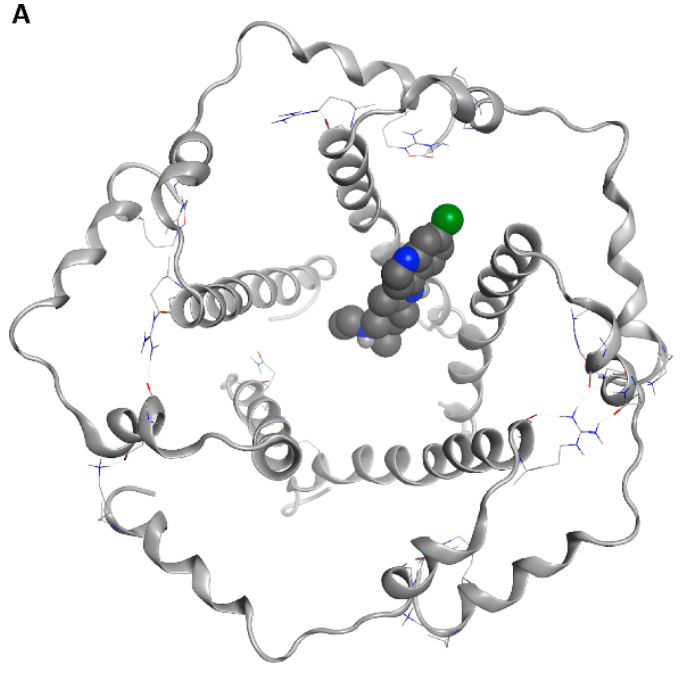

B

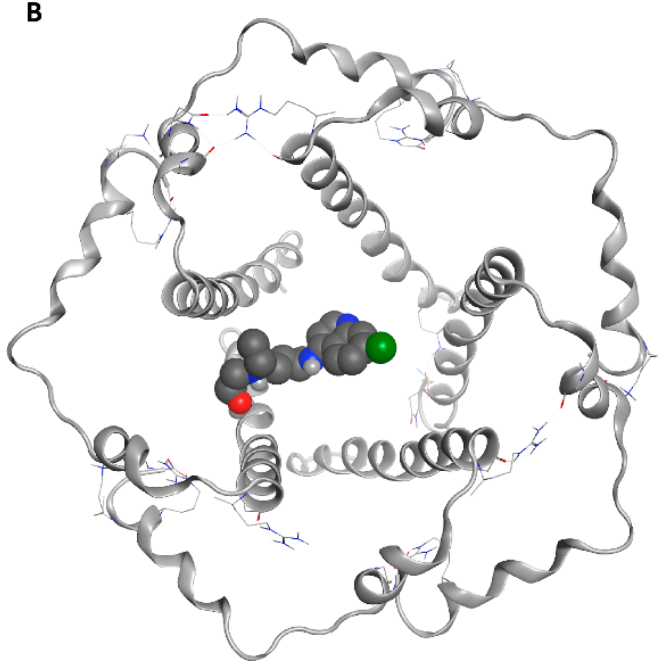

Figure 1. Docked poses of chloroquine (CQ) (A) and hydroxychloroquine (HCQ) (B) in the central cavity of the envelope (E) protein.

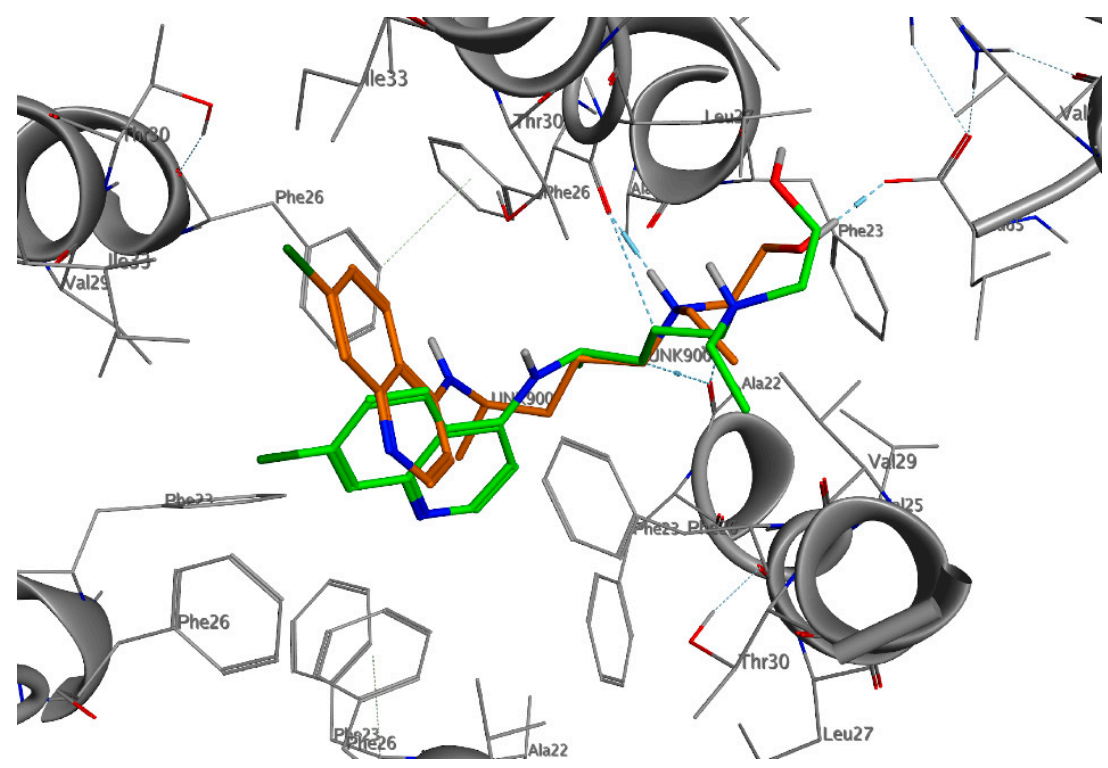

Figure 2. Three-dimensional (3D)-interaction diagram of HCQ in the docked pose (green) and average pose during molecular dynamics (MD) simulation (orange) with the E protein.

CQ adopts a position exactly opposite to that of HCQ (Figure 1). The quinolinic ring is inserted between two $\alpha$-helices of the pentameric structure establishing hydrophobic interactions with Val25, Phe26, Leu27, and Val29, while the small aliphatic chain is oriented within the channel (Figure S1). Among other things, in the tertiary amino group, it does not establish any interaction with the protein residues. During the MD simulation, the CQ moves along the central axis of the ion channel. After $5 \mathrm{~ns}$ of MD simulation, the drug stabilizes, establishing both hydrophobic interactions with Phe20, Ala22, Phe23, Val25, Phe26, and a hydrogen bond with Leu19, while the re-docking value $(-9.2 \mathrm{kcal} / \mathrm{mol})$ of the average poses confirms the excellent stability of the complex.

The ionic channels undergo significant conformational changes so that they perform their biological role. These membrane proteins have high plasticity, and some amino acids perform essential functions for the passage from closed to open state. During the MD simulation, we noticed a change in the volume of the central tunnel (the CQ led to an increase in the volume of the central lumen of $31.8 \%$ ), while HCQ reduced the volume of the cavity by $28.14 \%$. Both values refer to the volume of the central cavity of the protein without any ligand inside after $20 \mathrm{~ns}$ of MD simulation. We hypothesized that 
the two drugs interact differently with some central lumen residues, influencing its ability to change its conformation during its functionality. Probably, CQ could destabilize the ion channel structure by removing Phe26 residues from the center of the cavity, causing an expansion of the ion channel; conversely, the hydrophobic interactions of HCQ with the Phe26 (A-E) residues increase the stability of the central pore by bringing the chains of the pentameric structure closer, causing a reduction in the internal volume.

\subsection{NSP10/NSP14}

Nsp14 is a nonstructural protein of coronaviruses. It is known that nsp14 had two different roles showing both a proofreading activity [83] and methylase activity [84]. Nsp14 is a nonstructural $\mathrm{CoV}-2$ protein involved in virus replication fidelity by binding its proofreading subunit to the CoV-2 RNA polymerase [85]. Moreover, it has been shown that the nsp14, through its exonuclease domain, reduced mismatch during replication [86-88]. Notably, this mismatch repair activity has been related to the low mutation rate of SARS-CoV [62]. Furthermore, an accurate exonuclease activity represents an essential factor that could affect the activity and use of nucleoside analogs in the treatment of Coronavirus infections [89].

Nsp10, a nonstructural protein of 139 amino acids, is a most conserved protein of the replicative machine of SARS-CoV [90] and has been considered as a crucial multifunctional cofactor in their replication [91]. Although nsp10 is showing no enzyme activity, its role seems to be central to two distinct regulatory mechanisms: In fact, as reported by Bouvet et al., nsp10 interacts with both nsp14 and nsp16 triggering $3^{\prime}, 5^{\prime}$-exoribonuclease and $2^{\prime}$-O-methyltransferase activities, respectively [92-95]. Therefore, an interaction with nsp1, nsp7, nsp13, and itself has been also reported [91,96]. Probably, such interaction with itself may explain why peptides derived from the interaction domain of nsp10 with nsp16 have been shown to inhibit the activity of 2'-O-methyltransferase complex nsp10/nsp16 SARS-CoV [96].

The $N$-terminal exoribonuclease (ExoN) domain plays a proofreading role in the prevention of mutagenesis, while the $C$-terminal domain functions as a (guanine-N7) methyltransferase (N7-MTase) for mRNA capping. The nsp10 protein interacts with nsp14 ExoN to stabilize it and stimulate its activity [62]. The cap-precursor guanosine-P3-adenosine- $5^{\prime}, 5^{\prime}$-triphosphate, and $S$-adenosyl methionine bind in proximity in a very tight pocket between two $\beta$-sheets to accomplish methyl transfer. Assembly of a cap1 structure at the $5^{\prime}$ end of viral mRNA assists in translation and evading the host defense [97-99]. In the absence of nsp10, nsp14 cannot catalyze nucleotide excision efficiently. The structure of the nsp10/nsp14 complex explains this requirement of nsp10 for the enzymatic activity of nsp14. The extensive interaction of nsp10 with nsp14 suggests that nsp10 might be necessary to maintain the structural stability of the ExoN domain and fully unleash the ExoN activity of nsp14 [62].

We speculated on both domains to find a possible inhibitory activity of CQ and HCQ. Table 1 summarizes the binding energies of the two drugs in both the active sites. HCQ is more active than CQ in both sites, with a binding energy value of $-7.0 \mathrm{kcal} / \mathrm{mol}$ for the N7-MTase domain and $-7.3 \mathrm{kcal} / \mathrm{mol}$ for the ExoN domain. The binding energy values for CQ are -6.2 and $-6.0 \mathrm{kcal} / \mathrm{mol}$, respectively.

Table 1. Calculated free binding energies $\left(\Delta G_{\mathrm{B}}\right.$, in $\left.\mathrm{kcal} / \mathrm{mol}\right)$ of CQ and HCQ in N7-MTase and ExoN domains.

\begin{tabular}{ccc}
\hline Compound & N7-MTase (kcal/mol) & ExoN (kcal/mol) \\
\hline CQ & -6.2 & -6.0 \\
HCQ & -7.0 & -7.3 \\
\hline
\end{tabular}

As shown in Figure 3, both drugs have an overlapping pose in the N7-MTase domain. The hydrogens of the tertiary amino group form a hydrogen bond with the carboxyl group of Asp352, while the hydroxyl group in the HCQ forms hydrogen bonds with the carbonyl group of Gln354 and the amide hydrogen of Val296 at 1.7 and $2.2 \AA$, respectively, giving a higher energy binding 
value. The quinolinic ring, inside the pocket, is stabilized by the $\pi-\pi$ interaction with Phe426, and the chlorine atom establishes hydrophobic interactions with The401, Tyr401, and Phe506. Moreover, for the ExoN domain, the poses of CQ and HCQ are very similar. In both cases, the secondary and tertiary amino nitrogen form a bidentate hydrogen bond with Glu92, while the quinolinic ring establishes cation- $\pi$ interactions with the magnesium atom and Asp90. The hydrophobic and Van der Waals interactions with Va191, Trp186, Ala187, Phe190, Glu191, and Leu253 further stabilize the aromatic region of the ligands.
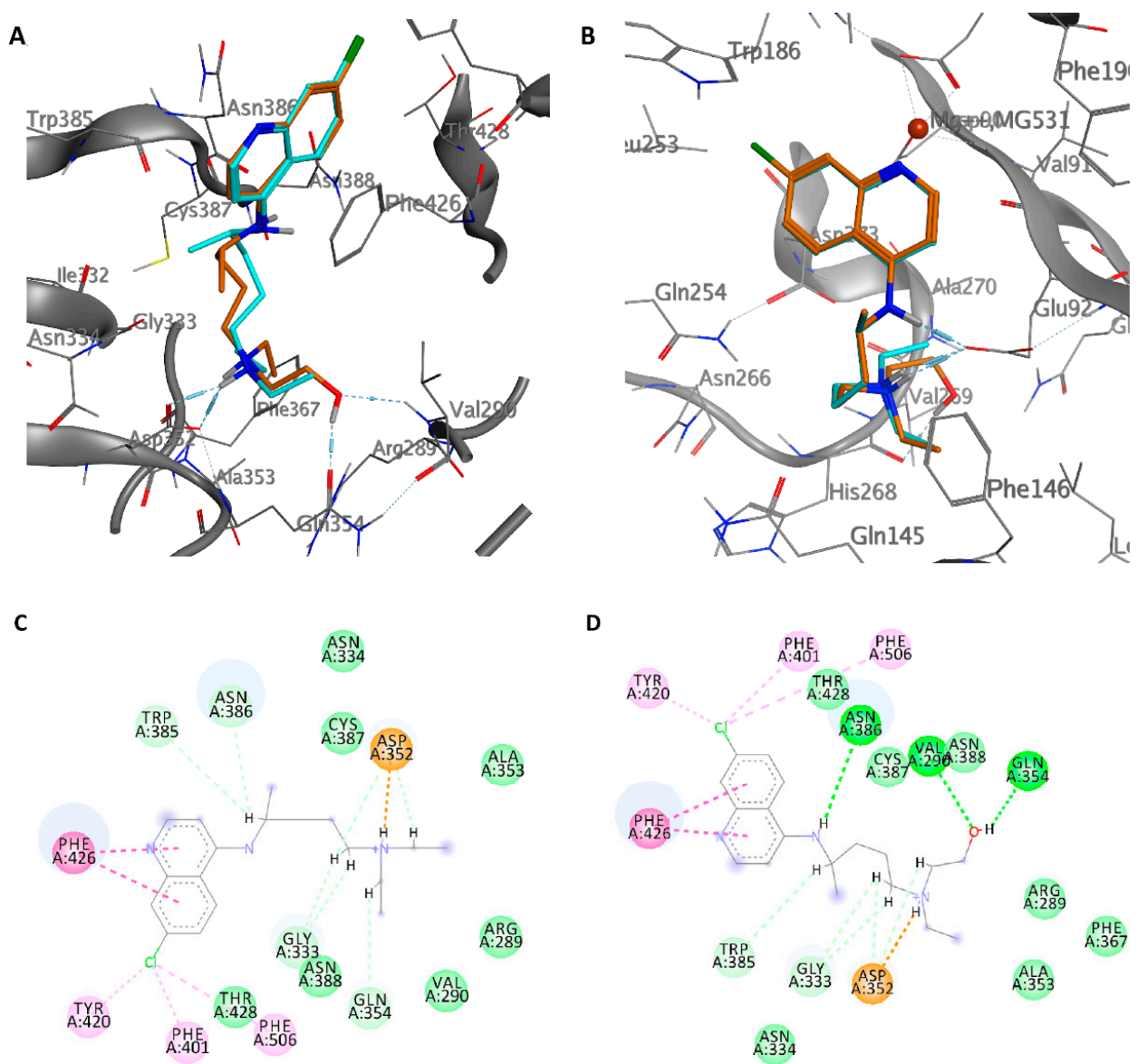

D
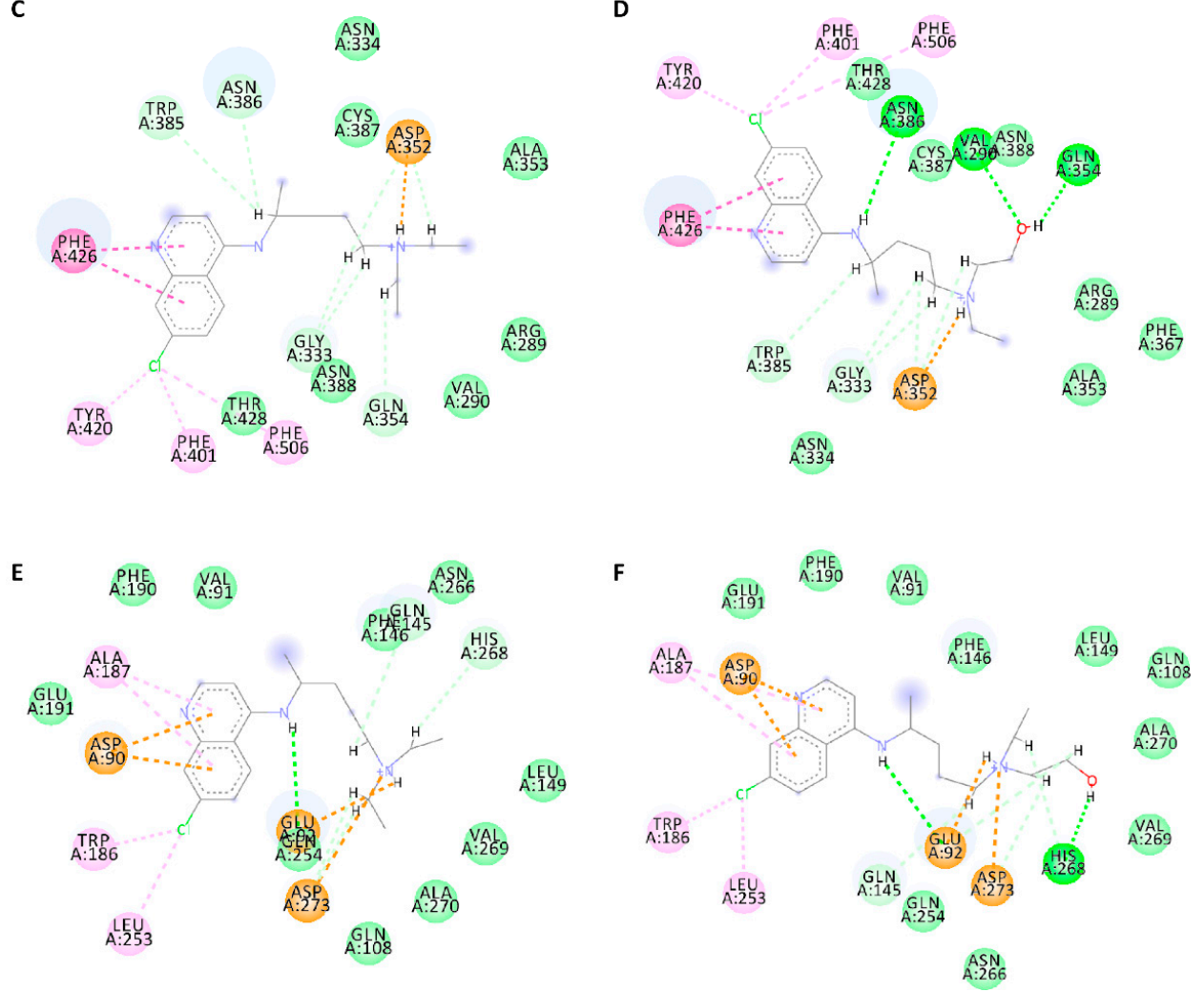

Figure 3. Interaction profile of the best-docked poses for CQ (blue) and HCQ (orange) in the N7-MTase (A) and ExoN (B) domain. Two-dimensional (2D) interaction diagram of CQ (C) and HCQ (D) in N7-MTase domain, and CQ (E) and HCQ (F) in ExoN domain.

MD simulations were performed to verify the stability of the complexes. At the N7-MTase site, HCQ showed better stability than CQ throughout the MD simulation period, with less square root 
mean deviation (RMSD) of both the ligand and the protein system (Figures S3 and S4). The hydrogen bond between the tertiary amine nitrogen atom and Asp352 was stable, with an average length of $1.78 \AA$, as well as the hydrogen bond between the oxygen of the hydroxyl group and Asn354, with an average length of $1.86 \AA$. The mean RMSD value of the protein backbone atoms is estimated $1.95 \AA$ for the HCQ complex and $2.14 \AA$ for the CQ one. Although the two systems showed good stability, the interaction with HCQ was more efficient throughout the MD simulation.

The study of the trajectories of the complexes in the ExoN domain allowed us to ascertain better stability of HCQ compared to CQ. The former maintained a better RMDS with an average value of $1.58 \AA$ compared to $1.71 \AA$ of the CQ. Even the RMSD of the protein structure underwent fewer fluctuations than the starting structure. It was interesting to note that HCQ maintained the hydrogen bond bidentate throughout the MD simulation, unlike $\mathrm{CQ}$, which preferred a more linear pose along with the active site (Figures S5 and S6).

In the absence of nsp10, nsp14 cannot catalyze nucleotide excision efficiently [62]. The structure of the nsp10/nsp14 complex explains this requirement of nsp10 for the enzymatic activity of nsp14. The primary residues that contribute to the nsp14-nsp10 interaction belong to two specific regions of the nsp10. The first contact area involves the $N$-terminal ring and the $\alpha 1$-helix (Pro1-Leu24) of nsp10, which led to an electron density interpretable for the first nine residues of nsp10. The residues Ala1, Asn3, and Glu6 of nsp10 stabilize the $N$-terminal region of nsp14 forming hydrogen bonds with Lys9, Asp10, and Thr5, while Phe16, Phe19, and Val21 of nsp10 form Van der Waals interactions with Phe60, Met62, and Tyr64 of nsp14. The second area of intermolecular interactions is extensive and includes residues from the ring region after the $\alpha 2$-helix and residues close to the zinc atom. Numerous complementary hydrogen bonds are observed here; Asn40, Lys43, Leu45, Thr58, Ser72, Lys93, and Tyr96 of nsp10 interact with Thr25, His26, Cys39, Asp41, Ala23, Tyr51, and His19 of the nsp14 N-terminal domain. A salt bridge formed between His80 of nsp10 and Asp126 of nsp14 and a hydrogen bond between Cys 90 of nsp10 and Asn129 of nsp14 stabilize the structural elements between $\beta 5$ and $\beta 6$ of nsp14 (Figure 4A). The extensive interactions of the nsp10 with the nsp14 suggest that the nsp10 may be necessary to maintain the structural stability of the ExoN domain of the nsp14 and simultaneously stimulate and maximize its activity [93].
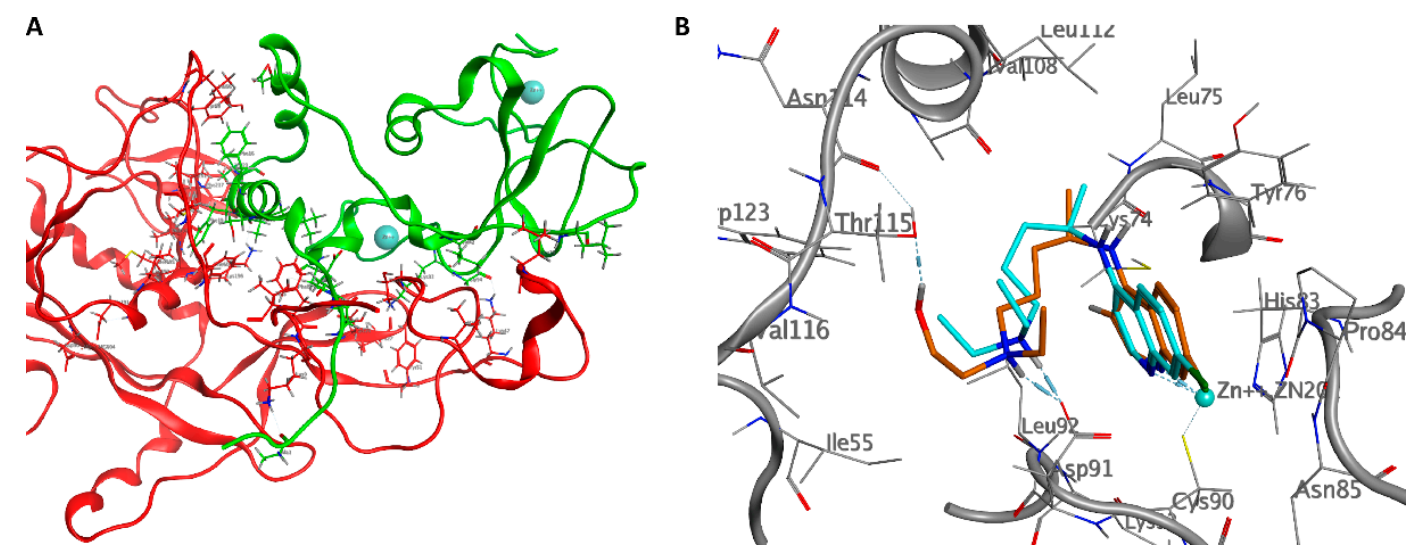

Figure 4. (A) Intermolecular interactions between nsp14 (red) is stabilized by nsp10 (green). Zinc ions are represented as blue spheres. (B) Docked poses of CQ (blue) and HCQ (orange) are shown with the residues of the binding pocket and the residues interacting with the nsp10 cavity.

We assumed that the drugs could interact with the nsp10/nsp14 domain by destabilizing the protein-protein complex. The docking results showed no significant interaction in the contact region between the two proteins; however, interesting results were obtained in a small pocket near the zinc atom of nsp10. The two drugs had the following energy binding: $-7.7 \mathrm{kcal} / \mathrm{mol}$ for HCQ and $-6.6 \mathrm{kcal} / \mathrm{mol}$ for CQ. 
The two drugs have a very similar pose. The nitrogen of the quinolinic ring establishes a coordination bond with the zinc atom, Van der Waals interactions with Cys74, Asn85, and Thr111, and $\pi-\pi$ interactions with Tyr76. The amine forms a salt bridge with Asp91 at $2.06 \AA$, while the hydroxyl group of HCQ establishes a hydrogen bond with the carbonyl oxygen of Thr115 at $1.97 \AA$ (Figure 4B).

\subsection{NSP10/NSP16}

Nsp16 is a 298 amino acids protein that is involved in methylation of the $2^{\prime}$-hydroxy group of adenines using $S$-adenosylmethionine as a source of methyl $[100,101]$. However, the nsp16 protein is an RNA cap-modifying enzyme that is devoid of any enzymatic activity, but it is activated by nsp10, which interacts with nsp16 and selectively confers upon its 2'-O-MTase activity on N7-methyl guanine RNA caps [102]. Nsp16 is also involved in the modulation of pathogenesis and type I Interferon susceptibility, as well as it has been suggested as a vaccine candidate [103].

The crystal structure of the nsp10/nsp16 methyltransferase (PDB ID: 6W6L) of SARS-CoV-2 was used for docking purposes. The docking results we obtained show that the two drugs have a very similar pose inside the pocket that binds SAM, despite the hydroxyquinoline having a better energy binding $(-8.1$ versus $-7.6 \mathrm{kcal} / \mathrm{mol})$. The quinolinic ring shows a hydrogen bond with the amide residue Cys6913 and hydrophobic interactions with Leu6898, Phe6947, and Met6929. The tertiary amino nitrogen atom of CQ forms a salt bridge with Gly9869, while that of HCQ with the carbonyl oxygen of Asp6928; the alcoholic group of HCQ forms hydrogen bonds with the carboxylic residue of Asp6928 (1.87 $⿱$ A) and the amino group of Lys6869 (1.98 ̊) (Figure 5). Probably, the further interaction of the hydroxyl group in the HCQ, inside the enzyme pocket, increases the affinity of the drug.

A

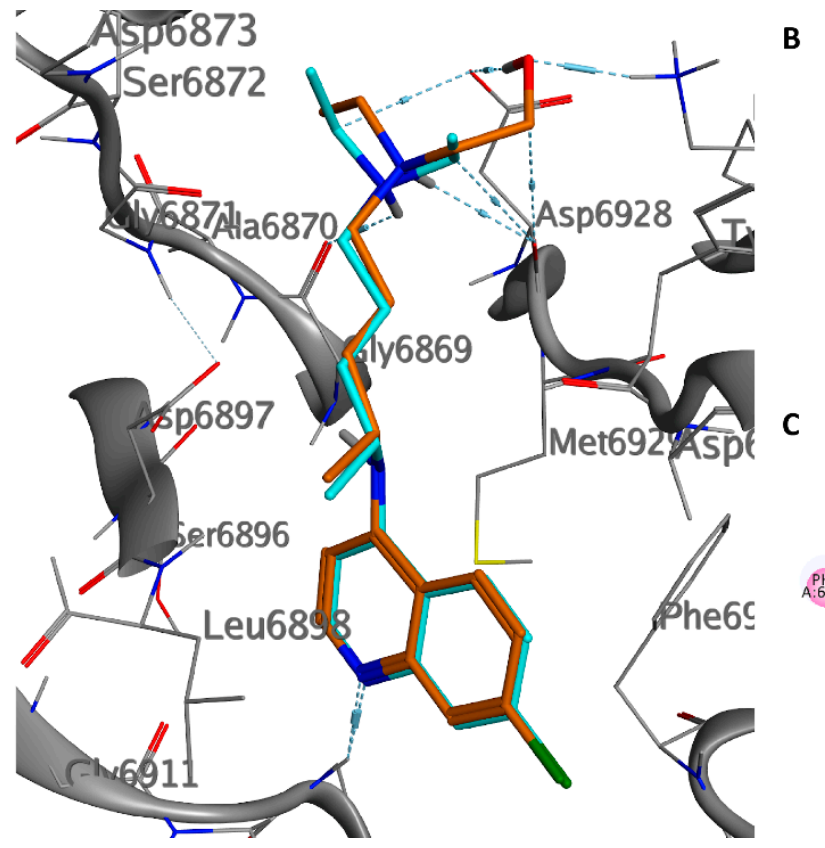

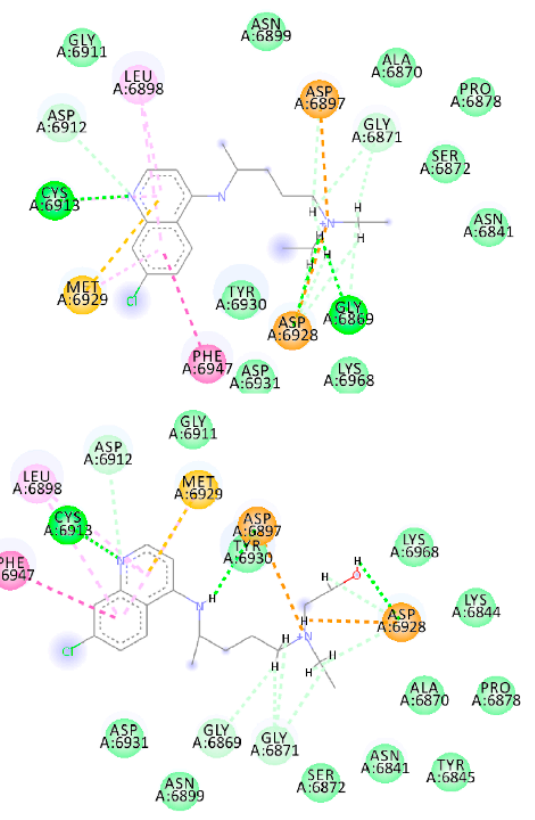

Figure 5. Interaction profile of the best-docked poses for CQ (blue) and HCQ (orange) in the SAM domain of nsp16 (A). 2D interaction diagram of CQ (B) and HCQ (C) in the SAM domain of nsp16.

The average pose in MD simulation showed that HCQ improves interactions with the active site, the hydrogen bonds with Asp6897, and Asp6928 whereas CQ maintains a stable pose demonstrating the low RMSD value (Figures S7 and S8). 


\section{Materials and Methods}

\subsection{Structures Preparation and Minimization}

The structures of all the molecules used in this study were built using Marvin Sketch (18.24, ChemAxon Ltd., Budapest, Hungary, http://www.chemaxon.com). A first molecular mechanics energy minimization was used for 3D structures created from the SMLES; the Merck molecular force field (MMFF94) present in Marvin Sketch was used. The protonation states were calculated, assuming a neutral pH. The PM3 Hamiltonian, as implemented in the MOPAC package (MOPAC2016 v. 18.151, Stewart Computational Chemistry, Colorado Springs, CO, USA) [104], was then used to further optimize the 3D structures before the alignment for the docking calculations.

\subsection{Molecular Docking}

Flexible ligand docking experiments were performed by employing the AutoDock 4.2.6 software implemented in YASARA (v. 19.5.5, YASARA Biosciences GmbH, Vienna, Austria) [105,106], using the three-dimensional crystal structure of the SARS coronavirus nsp10/nsp14 complex with functional ligands SAH and GpppA (PDB ID: 5C8S), NMR structure of the SARS coronavirus E protein pentameric ion channel (PDB ID: $5 \times 29$ ), and nsp10/nsp16 complex (PDB ID: 6W61) obtained from the Protein Data Bank (PDB, http://www.rcsb.org/pdb), the Lamarckian genetic algorithm (LGA). The crystallized ligand has been eliminated using the YASARA software. The maps were generated by the program AutoGrid (4.2.6) with a spacing of $0.375 \AA$ and dimensions that encompass all atoms extending $5 \AA$ from the surface of the structure of the crystallized ligand. All parameters were inserted at their default settings, as previously reported $[107,108]$. In the docking tab, the macromolecule and ligand were selected, and GA parameters were set as ga_runs $=100$, ga_pop_size $=150$, ga_num_evals $=$ $25,000,000$,ga_num_generations $=27,000$,ga_elitism $=1$, ga_mutation_rate $=0.02$, ga_crossover_rate $=0.8$, ga_crossover_mode $=$ two points, ga_cauchy_alpha $=0.0$, ga_cauchy_beta $=1.0$, number of generations for picking worst individual $=10$.

\subsection{Molecular Dynamics Simulations}

The molecular dynamics simulations of the nsp10/nsp14/ligand complexes and E protein/ligand complexes were performed with the YASARA structure package. A periodic simulation cell with boundaries extending $8 \AA$ [109] from the surface of the complex was employed. The box was filled with water, with a maximum sum of all water bumps of $1.0 \AA$, and a density of $0.997 \mathrm{~g} \mathrm{~mL}^{-1}$.

The setup included an optimization of the hydrogen bonding network [110] to increase the solute stability, and a $\mathrm{p} K_{\mathrm{a}}$ prediction to fine-tune the protonation states of protein residues at the chosen $\mathrm{pH}$ of 7.4 [111]. $\mathrm{NaCl}$ ions were added with a physiological concentration of $0.9 \%$, with an excess of either $\mathrm{Na}$ or $\mathrm{Cl}$ to neutralize the cell. Water molecules were deleted to readjust the solvent density to $0.997 \mathrm{~g} / \mathrm{mL}$. The final system dimensions were approximately $80 \times 80 \times 130 \AA^{3}$ for nsp10/nsp $14 /$ ligand complexes and $94 \times 78 \times 94 \AA^{3}$ for E protein/ligand complexes.

To best represent the biological environment, for $\mathrm{E}$ protein/ligand complexes, each of the best pose ligand/receptor complex structure was immersed in a simulated bilayer membrane, in the above reported physiological environment conditions, and subjected to a molecular dynamics (MD) simulation. The simulation was set up automatically by first scanning the protein for exposed transmembrane helices (i.e., helices longer than 16 residues, with more than seven hydrophobic residues and more than three exposed ones (accessible side-chain surface area $>30 \%$ of maximum)). The major axis vectors of these helices (i.e., the direction vectors of the least-squares lines through the $\mathrm{C}_{\text {alpha }}$ atoms) were summed up to obtain the major axis of the protein, which was then oriented along the $Y$-axis, generally with respect to the plane of the membrane and the XZ plane. The best shift of the membrane along this major axis was obtained by scanning the protein for the region with the largest number of exposed hydrophobic residues (see definition above) and a width of $28 \AA$ (corresponding to the membrane core). 
Having placed an equilibrated membrane structure (consisting of $50 \%$ of phosphatidylcholine and $50 \%$ of phosphatidylethanolamine) at this location named 'MemCenterY', the system was enclosed in a simulation cell of size $(100 \times 80 \times 100) \AA$, and the protein was temporarily scaled by 0.9 along the $\mathrm{X}-\mathrm{Z}$ axes, and then, strongly clashing membrane lipids were deleted (lipids with an atom closer than $0.75 \AA$ to a protein atom). The temporary protein scaling, which was needed to avoid the deletion of too many lipids around the protein, was then slowly removed during a short simulation at $298 \mathrm{~K}$ in vacuum. The protein (with all of the atoms kept fixed) was scaled by 1.02 along the $X-Z$ axes every $200 \mathrm{fs}$, while the membrane was allowed to move, but was restrained to ideal geometry (by pulling lipid residues with an atom further than $21.5 \AA$ away from MemCenterY back into the membrane, and by pushing phosphorus atoms closer than $14 \AA$ to MemCenterY back outwards).

The simulations were run using the ff14SB force field [112] for the solute, with Lipid17, GAFF2 [113], and AM1BCC [114] for non-standard residues, and TIP3P for water.

As soon as the protein had reached its original size again, the protein side-chain $\mathrm{p} K_{\mathrm{a}} \mathrm{s}$ were predicted, protonation states were assigned according to $\mathrm{pH}$ 7.4, and the simulation cell was filled with water, $0.9 \% \mathrm{NaCl}$, and counter ions.

The main simulation was then run with a cutoff of $8 \AA$ for Van der Waals forces (the default used by AMBER) [115], and no cutoff was applied to electrostatic forces (using the Particle Mesh Ewald algorithm) [116], a four fs time-step, constrained hydrogen atoms, and at constant pressure and temperature (NPT ensemble) using algorithms described in detail previously [117]. The ligand force field parameters were generated with the AutoSMILES utility [114], which employs semiempirical AM1 geometry optimization and assignment of charges, followed by assignment of the AM1BCC atom and bond types with refinement using the RESP charges, and finally the assignments of general AMBER force field atom types. Optimization of the hydrogen bond network of the various enzyme-ligand complexes was obtained using the method established by Hooft et al. [110], in order to address ambiguities arising from multiple side-chain conformations and protonation states that are not well resolved in the electron density [118]. During the initial 250 ps, the membrane was restrained to avoid distortions while the simulation cell adapted to the pressure exerted by the membrane (see above; additionally, water molecules that got closer than $14 \AA$ to MemCenterY were pushed outside). The source code of this simulation protocol and visualizations of the individual steps can be found at www.yasara.org/membranemd.

After the membrane placement, a short MD was run on the solvent only. The entire system was then energy minimized using first a steepest descent minimization to remove conformational stress, followed by a simulated annealing minimization until convergence $(<0.01 \mathrm{kcal} / \mathrm{mol} \AA)$. The MD simulation was then initiated, using the NPT ensemble at $298 \mathrm{~K}$, and integration time steps for intramolecular and intermolecular forces every 1.25 and $2.5 \mathrm{fs}$, respectively.

Finally, $20 \mathrm{~ns}$ MD simulations without any restrictions were conducted, and the conformations of each system were recorded every $200 \mathrm{ps}$. On the averaged structure of the last $3 \mathrm{~ns}$ frames, a second cycle of energy minimization, identical to the first, was applied. After inspection of the solute RMSD as a function of simulation time, the last 3 ns averaged structures were considered for further analysis.

\section{Conclusions}

The antiviral effect of HCQ against the SARS-CoV-2 infection compared to QC in vitro has been demonstrated [119], although there are still controversial opinions on the clinical effect of these drugs. Our results suggested that HCQ has a better energy binding with the examined targets than $C Q$, mainly due to the hydrogen bonding of the hydroxyl group in HCQ with polar amino acid residues. E protein functionality, necessary in virus maturation processes, could be disrupted by $C Q$ and HCQ by interaction in the central cavity of the ion channel. Although the docking poses have a different orientation within the central lumen showing interactions with different regions of the protein, these can influence the flexibility of the protein structure. Furthermore, the results obtained hinted that proofreading and capping of viral RNA in SARS-CoV-2, carried out by nsp10/nsp14 and 
nsp10/nsp16, could be influenced by CQ and HCQ. The energy binding for nsp16 in the SAM domain was slightly higher than the viral regions of nsp14. MD simulation studies demonstrate the stability of drug interactions with the protein regions analyzed. Although computational studies deserve more attention for nsp10, we have shown that CQ and HQC have a good affinity with an area of the viral protein that could influence the cofactor effect against nsp14 and nsp16.

Supplementary Materials: Supplementary materials can be found at http://www.mdpi.com/1422-0067/21/16/5856/s1. Author Contributions: Conceptualization, A.R. and P.M.F.; methodology, D.G. and V.F.; software, A.R.; validation, D.G., V.F., and A.R.; formal analysis, D.G., A.R., and P.M.F.; investigation, V.F. and P.M.F.; resources, D.G. and A.R.; data curation, D.G., V.F., A.R., and P.M.F.; writing-original draft preparation, D.G. and V.F; writing — review and editing, A.R. and P.M.F.; supervision, A.R. and P.M.F.; project administration, A.R. All authors have read and agreed to the published version of the manuscript.

Funding: This research received no external funding.

Acknowledgments: Free academic license from ChemAxon for their suite of programs is gratefully acknowledged.

Conflicts of Interest: The authors declare no conflict of interest.

\section{References}

1. de Wit, E.; van Doremalen, N.; Falzarano, D.; Munster, V.J. SARS and MERS: Recent insights into emerging coronaviruses. Nat. Rev. Microbiol. 2016, 14, 523-534. [CrossRef] [PubMed]

2. Zhu, N.; Zhang, D.; Wang, W.; Li, X.; Yang, B.; Song, J.; Zhao, X.; Huang, B.; Shi, W.; Lu, R.; et al. A Novel Coronavirus from Patients with Pneumonia in China, 2019. N. Engl. J. Med. 2020, 382, 727-733. [CrossRef] [PubMed]

3. Hui, D.S.; Memish, Z.A.; Zumla, A. Severe acute respiratory syndrome vs. The Middle East respiratory syndrome. Curr. Opin. Pulm. Med. 2014, 20, 233-241. [CrossRef] [PubMed]

4. WHO. WHO Characterizes COVID-19 as a Pandemic; WHO: Geneva, Switzerland, 2020.

5. Yu, W.B.; Tang, G.D.; Zhang, L.; Corlett, R.T. Decoding the evolution and transmissions of the novel pneumonia coronavirus (SARS-CoV-2 / HCoV-19) using whole genomic data. Zool. Res. 2020, 41, 247-257. [CrossRef] [PubMed]

6. Andersen, K.G.; Rambaut, A.; Lipkin, W.I.; Holmes, E.C.; Garry, R.F. The proximal origin of SARS-CoV-2. Nat. Med. 2020, 26, 450-452. [CrossRef] [PubMed]

7. Malaiyan, J.; Arumugam, S.; Mohan, K.; Gomathi Radhakrishnan, G. An update on the origin of SARS-CoV-2: Despite closest identity, bat (RaTG13) and pangolin derived coronaviruses varied in the critical binding site and O-linked glycan residues. J. Med. Virol. 2020. [CrossRef]

8. Tang, X.L.; Wu, C.C.; Li, X.; Song, Y.H.; Yao, X.M.; Wu, X.K.; Duan, Y.G.; Zhang, H.; Wang, Y.R.; Qian, Z.H.; et al. On the origin and continuing evolution of SARS-CoV-2. Natl. Sci. Rev. 2020, 7, 1012-1023. [CrossRef]

9. Chaw, S.M.; Tai, J.H.; Chen, S.L.; Hsieh, C.H.; Chang, S.Y.; Yeh, S.H.; Yang, W.S.; Chen, P.J.; Wang, H.Y. The origin and underlying driving forces of the SARS-CoV-2 outbreak. J. Biomed. Sci. 2020, 27. [CrossRef]

10. Rothan, H.A.; Byrareddy, S.N. The epidemiology and pathogenesis of coronavirus disease (COVID-19) outbreak. J. Autoimmun. 2020, 109, 102433. [CrossRef]

11. Robinson, C.; Loeffelholz, M.J.; Pinsky, B.A. Clinical Virology Manual. In Clinical Virology Manual, 5th ed.; Loeffelholz, M.J., Ed.; ASM Press: Washington, DC, USA, 2016.

12. Carriere, F.; Longhi, S.; Record, M. The endosomal lipid bis(monoacylglycero) phosphate as a potential key player in the mechanism of action of chloroquine against SARS-COV-2 and other enveloped viruses hijacking the endocytic pathway. Biochimie 2020. [CrossRef]

13. Gao, Q. Pharmacological characteristics of chloroquine and suggestions for its use in treatment of coronavirus disease 2019 (COVID-19). Zhongguo Xue Xi Chong Bing Fang Zhi Za Zhi 2020, 32, 119-122.[CrossRef] [PubMed]

14. Beura, S.; Prabhakar, C. In-silico strategies for probing chloroquine based inhibitors against SARS-CoV-2. J. Biomol. Struct. Dyn. 2020, 1-25. [CrossRef] [PubMed]

15. Rodriguez-Martinez, C.E.; Fernandes, R.M.; Hawcutt, D.B.; Sinha, I.P.; Pacheco, R.L. Efficacy, safety and cost-effectiveness of hydroxychloroquine in children with COVID-19: A call for evidence. Acta Paediatr. 2020. [CrossRef] [PubMed] 
16. D'Cruz, M. The ICMR bulletin on targeted hydroxychloroquine prophylaxis for Covid-19: Need to interpret with caution. Indian J. Med. Ethics 2020, 5, 100-102. [CrossRef] [PubMed]

17. Coatney, G.R. Pitfalls in a discovery: The chronicle of chloroquine. Am. J. Trop. Med. Hyg. 1963, 12, 121-128. [CrossRef] [PubMed]

18. Radl, S. From chloroquine to antineoplastic drugs? the story of antibacterial quinolones. Arch. Pharm. (Weinh.) 1996, 329, 115-119. [CrossRef] [PubMed]

19. Loeb, F.; Clark, W.M.; Coatney, G.R.; Coggeshall, L.T.; Dieuaide, F.R.; Dochez, A.R.; Marshall, E.K., Jr.; Marvel, C.S.; McCay, O.R.; Sapero, J.J.; et al. ACTIVITY of a new antimalarial agent, chloroquine (SN 7618). J. Am. Med. Assoc. 1946, 130, 1069. [CrossRef]

20. Halawani, A.; Baz, I.I.; Morcos, F. The antimalarial chloroquine-diphosphate (aralen). J. Egypt. Med. Assoc. 1947, 30, 128-136.

21. Anonimous, TRIAL use of the new antimalarial drug chloroquine. Bull. US Army. Med. Dep. 1946, 6, 9-10.

22. Anonimous, CHLOROQUINE-DIPHOSPHATE, a Newly-Standardized Antimalarial Drug. Bull. US Army. Med. Dep. 1947, 7, 834.

23. Anonimous, CLINICAL evaluation of chloroquine. Bull U S Army. Med. Dep. 1947, 7, 835-837.

24. Cowman, A.F.; Foote, S.J. Chemotherapy and Drug-Resistance in Malaria. Int. J. Parasitol. 1990, $20,503-513$. [CrossRef]

25. Ciak, J.; Hahn, F.E. Chloroquine: Mode of action. Science 1966, 151, 347-349. [CrossRef] [PubMed]

26. Whichard, L.P.; Washington, M.E.; Holbrook, D.J., Jr. The inhibition in vitro of bacterial DNA polymerases and RNA polymerase by antimalarial 8-aminoquinolines and by chloroquine. Biochim. Biophys. Acta 1972, 287, 52-67. [CrossRef]

27. Marquez, V.E.; Cranston, J.W.; Ruddon, R.W.; Burckhalter, J.H. Binding to deoxyribonucleic acid and inhibition of ribonucleic acid polymerase by analogs of chloroquine. J. Med. Chem. 1974, 17, 856-862. [CrossRef] [PubMed]

28. Conklin, K.A.; Heu, P.; Chou, S.C. The effects of antimalarial drugs on nucleic acid synthesis in vitro in Tetrahymena pyriformis. Mol. Pharm. 1973, 9, 304-310.

29. Field, R.C.; Gibson, B.R.; Holbrook, D.J., Jr.; McCall, B.M. Inhibition of precursor incorporation into nucleic acids of mammalian tissues by antimalarial aminoquinolines. Br. J. Pharm. 1978, 62, 159-164. [CrossRef]

30. Egan, T.J.; Marques, H.M. The role of haem in the activity of chloroquine and related antimalarial drugs. Coord. Chem. Rev. 1999, 190, 493-517. [CrossRef]

31. Pareja-Coronel, A. Treatment of viral hepatitis with chloroquine. Am. J. Gastroenterol. 1963, 39, $288-298$.

32. Mallucci, L. Effect of chloroquine on lysosomes and on growth of mouse hepatitis virus (MHV-3). Virology 1966, 28, 355-362. [CrossRef]

33. Yielding, K.L. Inhibition of the replication of a bacterial DNA virus by chloroquine and other 4-aminoquinoline drugs. Proc. Soc. Exp. Biol. Med. 1967, 125, 780-783. [CrossRef] [PubMed]

34. Inglot, A.D. Comparison of the antiviral activity in vitro of some non-steroidal anti-inflammatory drugs. J. Gen. Virol. 1969, 4, 203-214. [CrossRef] [PubMed]

35. Durand, D.P.; Chalgren, S.D.; Franke, V. Effect of chloroquine on myxovirus replication. Antimicrob Agents Chemother (Bethesda) 1970, 10, 105-108. [PubMed]

36. Pazmino, N.H.; Yuhas, J.M.; Tennant, R.W. Inhibition of murine RNA tumor virus replication and oncogenesis by chloroquine. Int. J. Cancer 1974, 14, 379-385. [CrossRef]

37. Rolain, J.M.; Colson, P.; Raoult, D. Recycling of chloroquine and its hydroxyl analogue to face bacterial, fungal and viral infections in the 21st century. Int. J. Antimicrob. Agents 2007, 30, 297-308. [CrossRef]

38. Al-Bari, M.A.A. Targeting endosomal acidification by chloroquine analogs as a promising strategy for the treatment of emerging viral diseases. Pharmacol. Res. Perspect. 2017, 5. [CrossRef]

39. D'Alessandro, S.; Scaccabarozzi, D.; Signorini, L.; Perego, F.; Ilboudo, D.P.; Ferrante, P.; Delbue, S. The Use of Antimalarial Drugs against Viral Infection. Microorganisms 2020, 8, 85. [CrossRef]

40. Devaux, C.A.; Rolain, J.M.; Colson, P.; Raoult, D. New insights on the antiviral effects of chloroquine against coronavirus: What to expect for COVID-19? Int. J. Antimicrob. Agents 2020, 55, 105938. [CrossRef]

41. Kooi, C.; Cervin, M.; Anderson, R. Differentiation of acid-pH-dependent and -nondependent entry pathways for mouse hepatitis virus. Virology 1991, 180, 108-119. [CrossRef] 
42. Zeichhardt, H.; Wetz, K.; Willingmann, P.; Habermehl, K.O. Entry of poliovirus type 1 and Mouse Elberfeld (ME) virus into HEp-2 cells: Receptor-mediated endocytosis and endosomal or lysosomal uncoating. J. Gen. Virol. 1985, 66, 483-492. [CrossRef]

43. Kronenberger, P.; Vrijsen, R.; Boeye, A. Chloroquine induces empty capsid formation during poliovirus eclipse. J. Virol. 1991, 65, 7008-7011. [CrossRef] [PubMed]

44. Savarino, A.; Lucia, M.B.; Rastrelli, E.; Rutella, S.; Golotta, C.; Morra, E.; Tamburrini, E.; Perno, C.F.; Boelaert, J.R.; Sperber, K.; et al. Anti-HIV effects of chloroquine: Inhibition of viral particle glycosylation and synergism with protease inhibitors. J. Acquir. Immune Defic. Syndr. 2004, 35, 223-232. [CrossRef]

45. Vincent, M.J.; Bergeron, E.; Benjannet, S.; Erickson, B.R.; Rollin, P.E.; Ksiazek, T.G.; Seidah, N.G.; Nichol, S.T. Chloroquine is a potent inhibitor of SARS coronavirus infection and spread. Virol. J. 2005, 2, 69. [CrossRef] [PubMed]

46. Ferri, C.; Sebastiani, M.; Antonelli, A.; Colaci, M.; Manfredi, A.; Giuggioli, D. Current treatment of hepatitis C-associated rheumatic diseases. Arthritis Res. 2012, 14. [CrossRef] [PubMed]

47. Marti-Carvajal, A.; Ramon-Pardo, P.; Javelle, E.; Simon, F.; Aldighieri, S.; Horvath, H.; Rodriguez-Abreu, J.; Reveiz, L. Interventions for treating patients with chikungunya virus infection-related rheumatic and musculoskeletal disorders: A systematic review. PLoS ONE 2017, 12. [CrossRef]

48. Savarino, A.; Gennero, L.; Sperber, K.; Boelaert, J.R. The anti-HIV-1 activity of chloroquine. J. Clin. Virol. 2001, 20, 131-135. [CrossRef]

49. Romanelli, F.; Smith, K.M.; Hoven, A.D. Chloroquine and hydroxychloroquine as inhibitors of human immunodeficiency virus (HIV-1) activity. Curr. Pharm. Des. 2004, 10, 2643-2648. [CrossRef]

50. Bhushan, P.; Aggarwal, A.; Baliyan, V. Complete Clearance of Cutaneous Warts with Hydroxychloroquine: Antiviral Action? Indian J. Derm. 2014, 59. [CrossRef]

51. Andreani, J.; Le Bideau, M.; Duflot, I.; Jardot, P.; Rolland, C.; Boxberger, M.; Wurtz, N.; Rolain, J.M.; Colson, P.; La Scola, B.; et al. In vitro testing of combined hydroxychloroquine and azithromycin on SARS-CoV-2 shows synergistic effect. Microb. Pathog. 2020, 145, 104228. [CrossRef]

52. Meo, S.A.; Klonoff, D.C.; Akram, J. Efficacy of chloroquine and hydroxychloroquine in the treatment of COVID-19. Eur. Rev. Med. Pharm. Sci. 2020, 24, 4539-4547.

53. Sarma, P.; Kaur, H.; Kumar, H.; Mahendru, D.; Avti, P.; Bhattacharyya, A.; Prajapat, M.; Shekhar, N.; Kumar, S.; Singh, R.; et al. Virological and clinical cure in COVID-19 patients treated with hydroxychloroquine: A systematic review and meta-analysis. J. Med. Virol. 2020. [CrossRef]

54. Gentile, I.; Maraolo, A.E.; Piscitelli, P.; Colao, A. COVID-19: Time for Post-Exposure Prophylaxis? Int. J. Environ. Res. Public. Health 2020, 17, 3997. [CrossRef] [PubMed]

55. Fantini, J.; Chahinian, H.; Yahi, N. Synergistic antiviral effect of hydroxychloroquine and azithromycin in combination against SARS-CoV-2: What molecular dynamics studies of virus-host interactions reveal. Int. J. Antimicrob. Agents 2020, 106020. [CrossRef] [PubMed]

56. Quiros Roldan, E.; Biasiotto, G.; Magro, P.; Zanella, I. The possible mechanisms of action of 4-aminoquinolines (chloroquine/hydroxychloroquine) against Sars-Cov-2 infection (COVID-19): A role for iron homeostasis? Pharm. Res. 2020, 158, 104904. [CrossRef] [PubMed]

57. Ostaszewski, M.; Mazein, A.; Gillespie, M.E.; Kuperstein, I.; Niarakis, A.; Hermjakob, H.; Pico, A.R.; Willighagen, E.L.; Evelo, C.T.; Hasenauer, J.; et al. COVID-19 Disease Map, building a computational repository of SARS-CoV-2 virus-host interaction mechanisms. Sci Data 2020, 7, 136. [CrossRef] [PubMed]

58. Ou, X.; Liu, Y.; Lei, X.; Li, P.; Mi, D.; Ren, L.; Guo, L.; Guo, R.; Chen, T.; Hu, J.; et al. Characterization of spike glycoprotein of SARS-CoV-2 on virus entry and its immune cross-reactivity with SARS-CoV. Nat. Commun. 2020, 11, 1620. [CrossRef]

59. Hoffmann, M.; Kleine-Weber, H.; Schroeder, S.; Kruger, N.; Herrler, T.; Erichsen, S.; Schiergens, T.S.; Herrler, G.; Wu, N.H.; Nitsche, A.; et al. SARS-CoV-2 Cell Entry Depends on ACE2 and TMPRSS2 and Is Blocked by a Clinically Proven Protease Inhibitor. Cell 2020, 181, 271-280. [CrossRef]

60. Coutard, B.; Valle, C.; de Lamballerie, X.; Canard, B.; Seidah, N.G.; Decroly, E. The spike glycoprotein of the new coronavirus 2019-nCoV contains a furin-like cleavage site absent in $\mathrm{CoV}$ of the same clade. Antivir. Res. 2020, 176, 104742. [CrossRef]

61. Zhang, L.; Lin, D.; Sun, X.; Curth, U.; Drosten, C.; Sauerhering, L.; Becker, S.; Rox, K.; Hilgenfeld, R. Crystal structure of SARS-CoV-2 main protease provides a basis for design of improved alpha-ketoamide inhibitors. Science 2020, 368, 409-412. 
62. Ma, Y.; Wu, L.; Shaw, N.; Gao, Y.; Wang, J.; Sun, Y.; Lou, Z.; Yan, L.; Zhang, R.; Rao, Z. Structural basis and functional analysis of the SARS coronavirus nsp14-nsp10 complex. Proc. Natl. Acad. Sci. USA 2015, 112, 9436-9441. [CrossRef]

63. Schoeman, D.; Fielding, B.C. Coronavirus envelope protein: Current knowledge. Virol. J. 2019, 16, 69. [CrossRef] [PubMed]

64. Viswanathan, T.; Arya, S.; Chan, S.H.; Qi, S.; Dai, N.; Hromas, R.A.; Park, J.G.; Oladunni, F.; Martinez-Sobrido, L.; Gupta, Y.K. Structural Basis of RNA Cap Modification by SARS-CoV-2 Coronavirus. Nat. Commun. 2020, 11, 3718. [CrossRef] [PubMed]

65. Verdia-Baguena, C.; Nieto-Torres, J.L.; Alcaraz, A.; Dediego, M.L.; Enjuanes, L.; Aguilella, V.M. Analysis of SARS-CoV E protein ion channel activity by tuning the protein and lipid charge. Biochim. Biophys. Acta 2013, 1828, 2026-2031. [CrossRef] [PubMed]

66. DeDiego, M.L.; Nieto-Torres, J.L.; Jimenez-Guardeno, J.M.; Regla-Nava, J.A.; Castano-Rodriguez, C.; Fernandez-Delgado, R.; Usera, F.; Enjuanes, L. Coronavirus virulence genes with main focus on SARS-CoV envelope gene. Virus Res. 2014, 194, 124-137. [CrossRef] [PubMed]

67. Cohen, J.R.; Lin, L.D.; Machamer, C.E. Identification of a Golgi complex-targeting signal in the cytoplasmic tail of the severe acute respiratory syndrome coronavirus envelope protein. J. Virol. 2011, 85, 5794-5803. [CrossRef]

68. EA, J.A.; Jones, I.M. Membrane binding proteins of coronaviruses. Future Virol. 2019, 14, $275-286$.

69. Ruch, T.R.; Machamer, C.E. The coronavirus E protein: Assembly and beyond. Viruses 2012, 4, $363-382$. [CrossRef]

70. Liu, D.X.; Yuan, Q.; Liao, Y. Coronavirus envelope protein: A small membrane protein with multiple functions. Cell. Mol. Life Sci. 2007, 64, 2043-2048. [CrossRef]

71. Fung, T.S.; Liu, D.X. Post-translational modifications of coronavirus proteins: Roles and function. Future Virol. 2018, 13, 405-430. [CrossRef]

72. Yuan, Q.; Liao, Y.; Torres, J.; Tam, J.P.; Liu, D.X. Biochemical evidence for the presence of mixed membrane topologies of the severe acute respiratory syndrome coronavirus envelope protein expressed in mammalian cells. Febs Lett. 2006, 580, 3192-3200. [CrossRef]

73. Nieva, J.L.; Madan, V.; Carrasco, L. Viroporins: Structure and biological functions. Nat. Rev. Microbiol. 2012, 10, 563-574. [CrossRef] [PubMed]

74. Castano-Rodriguez, C.; Honrubia, J.M.; Gutierrez-Alvarez, J.; DeDiego, M.L.; Nieto-Torres, J.L.; Jimenez-Guardeno, J.M.; Regla-Nava, J.A.; Fernandez-Delgado, R.; Verdia-Baguena, C.; Queralt-Martin, M.; et al. Role of Severe Acute Respiratory Syndrome Coronavirus Viroporins E, 3a, and 8a in Replication and Pathogenesis. mBio 2018, 9, e02325-17. [CrossRef] [PubMed]

75. Ye, Y.; Hogue, B.G. Role of the coronavirus E viroporin protein transmembrane domain in virus assembly. J. Virol. 2007, 81, 3597-3607. [CrossRef]

76. Nieto-Torres, J.L.; Verdia-Baguena, C.; Jimenez-Guardeno, J.M.; Regla-Nava, J.A.; Castano-Rodriguez, C.; Fernandez-Delgado, R.; Torres, J.; Aguilella, V.M.; Enjuanes, L. Severe acute respiratory syndrome coronavirus E protein transports calcium ions and activates the NLRP3 inflammasome. Virology 2015, 485, 330-339. [CrossRef] [PubMed]

77. Lo, Y.H.; Huang, Y.W.; Wu, Y.H.; Tsai, C.S.; Lin, Y.C.; Mo, S.T.; Kuo, W.C.; Chuang, Y.T.; Jiang, S.T.; Shih, H.M.; et al. Selective inhibition of the NLRP3 inflammasome by targeting to promyelocytic leukemia protein in mouse and human. Blood 2013, 121, 3185-3194. [CrossRef] [PubMed]

78. DeDiego, M.L.; Alvarez, E.; Almazan, F.; Rejas, M.T.; Lamirande, E.; Roberts, A.; Shieh, W.J.; Zaki, S.R.; Subbarao, K.; Enjuanes, L. A severe acute respiratory syndrome coronavirus that lacks the E gene is attenuated in vitro and in vivo. J. Virol. 2007, 81, 1701-1713. [CrossRef]

79. Teoh, K.T.; Siu, Y.L.; Chan, W.L.; Schluter, M.A.; Liu, C.J.; Peiris, J.S.; Bruzzone, R.; Margolis, B.; Nal, B. The SARS coronavirus E protein interacts with PALS1 and alters tight junction formation and epithelial morphogenesis. Mol. Biol. Cell 2010, 21, 3838-3852. [CrossRef]

80. DeDiego, M.L.; Nieto-Torres, J.L.; Jimenez-Guardeno, J.M.; Regla-Nava, J.A.; Alvarez, E.; Oliveros, J.C.; Zhao, J.; Fett, C.; Perlman, S.; Enjuanes, L. Severe acute respiratory syndrome coronavirus envelope protein regulates cell stress response and apoptosis. PLoS Pathog. 2011, 7, e1002315. [CrossRef]

81. Scott, C.; Griffin, S. Viroporins: Structure, function and potential as antiviral targets. J. Gen. Virol. 2015, 96, 2000-2027. [CrossRef] 
82. Surya, W.; Li, Y.; Torres, J. Structural model of the SARS coronavirus E channel in LMPG micelles. Biochim. Biophys. Acta Biomembr. 2018, 1860, 1309-1317. [CrossRef]

83. Ogando, N.S.; Ferron, F.; Decroly, E.; Canard, B.; Posthuma, C.C.; Snijder, E.J. The Curious Case of the Nidovirus Exoribonuclease: Its Role in RNA Synthesis and Replication Fidelity. Front, Microbiol, 2019, 10, 1813. [CrossRef] [PubMed]

84. Chen, Y.; Cai, H.; Pan, J.; Xiang, N.; Tien, P.; Ahola, T.; Guo, D. Functional screen reveals SARS coronavirus nonstructural protein nsp14 as a novel cap N7 methyltransferase. Proc. Natl. Acad. Sci. USA 2009, 106, 3484-3489. [CrossRef] [PubMed]

85. Subissi, L.; Posthuma, C.C.; Collet, A.; Zevenhoven-Dobbe, J.C.; Gorbalenya, A.E.; Decroly, E.; Snijder, E.J.; Canard, B.; Imbert, I. One severe acute respiratory syndrome coronavirus protein complex integrates processive RNA polymerase and exonuclease activities. Proc. Natl. Acad. Sci. USA 2014, 111, E3900-E3909. [CrossRef] [PubMed]

86. Eckerle, L.D.; Lu, X.; Sperry, S.M.; Choi, L.; Denison, M.R. High fidelity of murine hepatitis virus replication is decreased in nsp14 exoribonuclease mutants. J. Virol. 2007, 81, 12135-12144. [CrossRef] [PubMed]

87. Eckerle, L.D.; Becker, M.M.; Halpin, R.A.; Li, K.; Venter, E.; Lu, X.; Scherbakova, S.; Graham, R.L.; Baric, R.S.; Stockwell, T.B.; et al. Infidelity of SARS-CoV Nsp14-exonuclease mutant virus replication is revealed by complete genome sequencing. PLoS Pathog. 2010, 6, e1000896. [CrossRef] [PubMed]

88. Denison, M.R.; Graham, R.L.; Donaldson, E.F.; Eckerle, L.D.; Baric, R.S. Coronaviruses: An RNA proofreading machine regulates replication fidelity and diversity. Rna Biol. 2011, 8, 270-279. [CrossRef] [PubMed]

89. Shannon, A.; Le, N.T.; Selisko, B.; Eydoux, C.; Alvarez, K.; Guillemot, J.C.; Decroly, E.; Peersen, O.; Ferron, F.; Canard, B. Remdesivir and SARS-CoV-2: Structural requirements at both nsp12 RdRp and nsp14 Exonuclease active-sites. Antivir. Res. 2020, 178, 104793. [CrossRef]

90. Neuman, B.W.; Chamberlain, P.; Bowden, F.; Joseph, J. Atlas of coronavirus replicase structure. Virus Res. 2014, 194, 49-66. [CrossRef]

91. Snijder, E.J.; Decroly, E.; Ziebuhr, J. The Nonstructural Proteins Directing Coronavirus RNA Synthesis and Processing. Adv. Virus Res. 2016, 96, 59-126.

92. Bouvet, M.; Debarnot, C.; Imbert, I.; Selisko, B.; Snijder, E.J.; Canard, B.; Decroly, E. In vitro reconstitution of SARS-coronavirus mRNA cap methylation. PLoS Pathog. 2010, 6, e1000863. [CrossRef]

93. Bouvet, M.; Imbert, I.; Subissi, L.; Gluais, L.; Canard, B.; Decroly, E. RNA 3'-end mismatch excision by the severe acute respiratory syndrome coronavirus nonstructural protein nsp10/nsp14 exoribonuclease complex. Proc. Natl. Acad. Sci. USA 2012, 109, 9372-9377. [CrossRef] [PubMed]

94. Bouvet, M.; Lugari, A.; Posthuma, C.C.; Zevenhoven, J.C.; Bernard, S.; Betzi, S.; Imbert, I.; Canard, B.; Guillemot, J.C.; Lecine, P.; et al. Coronavirus Nsp10, a critical co-factor for activation of multiple replicative enzymes. J. Biol. Chem. 2014, 289, 25783-25796. [CrossRef] [PubMed]

95. Lugari, A.; Betzi, S.; Decroly, E.; Bonnaud, E.; Hermant, A.; Guillemot, J.C.; Debarnot, C.; Borg, J.P.; Bouvet, M.; Canard, B.; et al. Molecular mapping of the RNA Cap 2'-O-methyltransferase activation interface between severe acute respiratory syndrome coronavirus nsp10 and nsp16. J. Biol. Chem. 2010, 285, 33230-33241. [CrossRef] [PubMed]

96. Ke, M.; Chen, Y.; Wu, A.; Sun, Y.; Su, C.; Wu, H.; Jin, X.; Tao, J.; Wang, Y.; Ma, X.; et al. Short peptides derived from the interaction domain of SARS coronavirus nonstructural protein nsp10 can suppress the 2'-O-methyltransferase activity of nsp10/nsp16 complex. Virus Res. 2012, 167, 322-328. [CrossRef]

97. Marcotrigiano, J.; Gingras, A.C.; Sonenberg, N.; Burley, S.K. Cocrystal structure of the messenger RNA 5' cap-binding protein (eIF4E) bound to 7-methyl-GDP. Cell 1997, 89, 951-961. [CrossRef]

98. Nallagatla, S.R.; Toroney, R.; Bevilacqua, P.C. A brilliant disguise for self RNA: 5 '-end and internal modifications of primary transcripts suppress elements of innate immunity. Rna Biol. 2008, 5, 140-144. [CrossRef]

99. Decroly, E.; Ferron, F.; Lescar, J.; Canard, B. Conventional and unconventional mechanisms for capping viral mRNA. Nat. Rev. Microbiol. 2011, 10, 51-65. [CrossRef]

100. Yoshimoto, F.K. The Proteins of Severe Acute Respiratory Syndrome Coronavirus-2 (SARS CoV-2 or n-COV19), the Cause of COVID-19. Protein J. 2020, 39, 198-216.

101. Decroly, E.; Imbert, I.; Coutard, B.; Bouvet, M.; Selisko, B.; Alvarez, K.; Gorbalenya, A.E.; Snijder, E.J.; Canard, B. Coronavirus nonstructural protein 16 is a cap-0 binding enzyme possessing (nucleoside-2'O)methyltransferase activity. J. Virol. 2008, 82, 8071-8084. [CrossRef] 
102. Encinar, J.A.; Menendez, J.A. Potential Drugs Targeting Early Innate Immune Evasion of SARS-Coronavirus 2 via 2'-O-Methylation of Viral RNA. Viruses 2020, 12, 525. [CrossRef]

103. Menachery, V.D.; Yount, B.L., Jr.; Josset, L.; Gralinski, L.E.; Scobey, T.; Agnihothram, S.; Katze, M.G.; Baric, R.S. Attenuation and restoration of severe acute respiratory syndrome coronavirus mutant lacking 2'-o-methyltransferase activity. J. Virol. 2014, 88, 4251-4264. [CrossRef] [PubMed]

104. Stewart, J.J.P. Optimization of parameters for semiempirical methods IV: Extension of MNDO, AM1, and PM3 to more main group elements. J. Mol. Model. 2004, 10, 155-164. [CrossRef] [PubMed]

105. Krieger, E.; Koraimann, G.; Vriend, G. Increasing the precision of comparative models with YASARA NOVA-a self-parameterizing force field. Proteins 2002, 47, 393-402. [CrossRef]

106. Krieger, E.; Vriend, G. YASARA View-Molecular graphics for all devices-From smartphones to workstations. Bioinformatics 2014, 30, 2981-2982. [CrossRef]

107. Floresta, G.; Patamia, V.; Gentile, D.; Molteni, F.; Santamato, A.; Rescifina, A.; Vecchio, M. Repurposing of FDA-Approved Drugs for Treating Iatrogenic Botulism: A Paired 3D-QSAR/Docking Approach. ChemMedChem 2020, 15, 256-262. [CrossRef] [PubMed]

108. Gentile, D.; Patamia, V.; Scala, A.; Sciortino, M.T.; Piperno, A.; Rescifina, A. Putative Inhibitors of SARS-CoV-2 Main Protease from A Library of Marine Natural Products: A Virtual Screening and Molecular Modeling Study. Mar. Drugs 2020, 18, 225. [CrossRef]

109. Duan, Y.; Wu, C.; Chowdhury, S.; Lee, M.C.; Xiong, G.; Zhang, W.; Yang, R.; Cieplak, P.; Luo, R.; Lee, T.; et al. A point-charge force field for molecular mechanics simulations of proteins based on condensed-phase quantum mechanical calculations. J. Comput. Chem. 2003, 24, 1999-2012. [CrossRef]

110. Krieger, E.; Dunbrack, R.L., Jr.; Hooft, R.W.; Krieger, B. Assignment of protonation states in proteins and ligands: Combining pKa prediction with hydrogen bonding network optimization. Methods Mol. Biol. 2012, $819,405-421$.

111. Krieger, E.; Nielsen, J.E.; Spronk, C.A.; Vriend, G. Fast empirical pKa prediction by Ewald summation. J. Mol. Graph. Model. 2006, 25, 481-486. [CrossRef]

112. Maier, J.A.; Martinez, C.; Kasavajhala, K.; Wickstrom, L.; Hauser, K.E.; Simmerling, C. ff14SB: Improving the Accuracy of Protein Side Chain and Backbone Parameters from ff99SB. J. Chem. Theory Comput. 2015, 11, 3696-3713. [CrossRef]

113. Wang, J.M.; Wolf, R.M.; Caldwell, J.W.; Kollman, P.A.; Case, D.A. Development and testing of a general amber force field. J. Comput. Chem. 2004, 25, 1157-1174. [CrossRef] [PubMed]

114. Jakalian, A.; Jack, D.B.; Bayly, C.I. Fast, efficient generation of high-quality atomic charges. AM1-BCC model: II. Parameterization and validation. J. Comput. Chem. 2002, 23, 1623-1641. [CrossRef] [PubMed]

115. Hornak, V.; Abel, R.; Okur, A.; Strockbine, B.; Roitberg, A.; Simmerling, C. Comparison of multiple amber force fields and development of improved protein backbone parameters. Proteins-Struct. Funct. Bioinform. 2006, 65, 712-725. [CrossRef] [PubMed]

116. Essmann, U.; Perera, L.; Berkowitz, M.L.; Darden, T.; Lee, H.; Pedersen, L.G. A smooth particle mesh Ewald method. J. Chem. Phys. 1995, 103, 8577-8593. [CrossRef]

117. Krieger, E.; Vriend, G. New Ways to Boost Molecular Dynamics Simulations. J. Comput. Chem. 2015, 36, 996-1007. [CrossRef]

118. Hooft, R.W.W.; Vriend, G.; Sander, C.; Abola, E.E. Errors in protein structures. Nature 1996, $381,272$. [CrossRef]

119. Liu, J.; Cao, R.; Xu, M.; Wang, X.; Zhang, H.; Hu, H.; Li, Y.; Hu, Z.; Zhong, W.; Wang, M. Hydroxychloroquine, a less toxic derivative of chloroquine, is effective in inhibiting SARS-CoV-2 infection in vitro. Cell Discov. 2020, 6, 16. [CrossRef]

(C) 2020 by the authors. Licensee MDPI, Basel, Switzerland. This article is an open access article distributed under the terms and conditions of the Creative Commons Attribution (CC BY) license (http://creativecommons.org/licenses/by/4.0/). 